\title{
Early Wound Complications And Influencing Factors For The Breast Cancer Patients After Oncoplastic Surgery
}

\section{Onkoplastik Cerrahi Uygulanan Meme Kanseri Hastalarında Erken Yara Komplikasyonları Ve Etki Eden Faktörler}

\author{
Gamze Kızıltan¹, Cihangir Özaslan², Niyazi Karaman², Lütfi Doğan² \\ ${ }^{1}$ Department of Surgery, Kırıkkale Yuksek Ihtisas Hospital, Kırıkkale, Turkey \\ ${ }^{2}$ Department of Surgery, Ankara Oncology Hospital, Ankara, Turkey
}

GİRIŞ̧ ve AMAÇ: Bu çalışmada meme kanseri tanısı almış ve onkoplastik cerrahi teknikleri ile tedavi edilmiş hastalarda gelişen erken dönem yara komplikasyonları ve bu komplikasyonlara etki eden faktörler araştırılmıştır. YÖNTEM ve GEREÇLER: Superior ve inferior pedikül onkoplastik cerrahi tekniklerinden biri uygulanarak opere edilmiş 77 hastaya ait veriler retrospektif olarak incelendi. Hastalara ait veriler ile yara komplikasyonlarının gelişip gelişmediği kayıt altına alındı.

BULGULAR: Yapılan istatistiksel değerlendirmeler sonucunda ileri yaş, hipertansiyon ve doku ağırlığının yara komplikasyon riskini arttırdığı tespit edilmiştir. Çıkarılan doku ağırlığı ve hipertansiyon bağımsız risk faktörü olarak saptanmıştır. Meme kanseri nedeni ile ameliyat edilen hastalardan oluşan serimizde minör komplikasyonlar \%23.4 oranında görülmüştür.

TARTIŞMA ve SONUÇ: Çalışmamızdaki minor komplikasyon oranı literatürde belirtilmiş komplikasyon oranları ile uyumludur. Hasta yaşı, yara iyileşmesini etkileyen komorbid hastalıklar ve çıkarılan doku hacmi arttıkça komplikasyon oranlarının arttığı bilinmektedir. İleri yaş ve komorbid hastalıkların varlığı komplikasyonları arttıran bir faktör olmakla birlikte ameliyat için kontrendikasyon teşkil etmez.Çalışmamız sonucunda elde ettiğimiz veriler de onkoplastik meme cerrahisinin, meme kanseri olan hastalarda klasik meme koruyucu cerrahi tekniklerinden daha geniş eksizyon imkanı sağladığı ve komplikasyon oranlarını arttırmadan güvenle kullanılabileceğini göstermektedir.

Anahtar Kelimeler: meme kanseri, onkoplastik meme cerrahisi, yara komplikasyonları

\begin{abstract}
INTRODUCTION: In this study, early wound complications and factors affecting these complications were investigated in patients diagnosed with breast cancer and treated with oncoplastic surgery techniques. METHODS: The data of 77 patients who underwent surgery with superior or inferior pedicle oncoplastic breast surgery techniques were retrospectively analyzed. The patients' data and the information about wound complications were recorded.

RESULTS: As a result of statistical evaluations, it was determined that age, hypertension and removed tissue weight increased the risk of wound complications. The removed tissue weight and hypertension were found to be independent risk factors. In our series, our minor complication rate is $23.4 \%$.

DISCUSSION and CONCLUSION: Minor complication rate of our series is similar with the literature. It is known that the complication rates increases with patient age, comorbid diseases and the amount of removed tissue volume. Age and the presence of comorbid diseases are some of the factors that increase complications, but not a contraindication for the surgery. The data obtained from our study showed that; since oncoplastic breast surgery provides wider excision than classical breast-conserving surgical techniques, it can be used safely without increasing complication rates in the patients.

Keywords: Breast cancer, oncoplastic breast surgery, wound complications
\end{abstract}




\section{INTRODUCTION}

Breast-conserving surgery (BCS), which is becoming widespread all over the world, is safe and effective for improving aesthetic outcomes and broadening the indication for BCS surgery towards larger tumors (1). The percentage of deformities requiring surgical correction, after standard BCS techniques and radiotherapy were found as $30 \%$ (2). These results not only make BCS deviate from its goal but also limits the application of this technique. Poor cosmetic results and development of asymmetry are frequently observed, especially in large breasts and when large tissues are removed with BCS. Radiotherapy after BCS in ptotic breasts becomes more difficult, and BCS may be contraindicated because of the inability to obtain an equal dose in these patients (3).

Oncoplastic surgical techniques allow wider surgical excision especially in cases with macromastia and ptosis and make breast cancer treatment possible with aesthetic satisfaction (4). Besides, patients with macromastia and breast cancer may also eliminate the complaints such as back, neck and shoulder pain due to macromastia.

The most common early wound complications reported after reduction mammoplasty are hematoma, seroma, wound dehiscence, more rarely NAC necrosis and flap necrosis.

The complication rates in literature and classification of surgical complications are very highly variable. Patient age and comorbid diseases are some factors that affects wound healing and increase complications in general. High complication rates may cause adjuvant treatment delays in breast cancer patients.

In this study, we evaluated the early wound complications and the factors affecting these complications among the patients who diagnosed with breast cancer and treated with oncoplastic surgical techniques.

\section{MATERIALS and METHODS}

Data of 77 patients, who treated using superior or inferior oncoplastic breast-conserving surgery (OBCS) techniques in our clinic between April 2007-December 2011 with breast cancer were analyzed retrospectively.
Patients treated with other oncoplastic methods were not included in this study. Patients with systemic metastases and patients who had OBCS after neoadjuvant chemotherapy were also excluded.

The inferior pedicle technique was preferred primarily for the tumors located in the lateral and medial areas of the breast and also for the tumors located above the nipple areola complex (NAC). The superior pedicle technique was preferred for the tumors located in the lower pole of the breast. The incision scar of the previous diagnostic biopsy was within the excision limits. Resection was performed according to oncological principles. In order to facilitate the planning of postoperative radiotherapy, the tumor localization was marked with titanium clips. A separate axillary incision was used for both SLNB and axillary dissection.

Operations to achieve contralateral breast symmetrization were performed based on patients' decision. Symmetrization procedures were performed at the same session using the same surgical technique.

Wound complications were evaluated in two groups as early and late. Wound dehiscence, areola necrosis, seroma, wound infection and hematoma development were evaluated as early complications.

All patients were called for follow-ups in every months of the first three months. Demographic data (age, sex, BMI(body mass index), comorbidities, tumor type, TNM stage, tumor localization) and surgical data (specimen weight, applied surgical technique) were recorded.

The data were recorded using SPSS version 15.0. For statistical analysis, NCSS (Number Cruncher Statistical System) \&PASS (Power Analysis and Sample Size) Statistical Software (Utah, USA) were used. In the evaluation of the study data, Mann Whitney U test was utilized to compare quantitative data, as well as the descriptive statistical methods (mean, standard deviation, median, frequency, ratio). Pearson Chi-square test, Fisher's Exact test, Yates Continuity Correction test and ODDS ratios were used to compare qualitative data. Backward Stepwise Logistic regression analysis was used to analyze the risk factors affecting early complications. The level of significance was evaluated as $\mathrm{p}<0.05$. 


\section{RESULTS}

Age of the patients varies between 28 and 71, and the mean age was determined as 51,69 \pm 9.42 years. $41.6 \%(n=32)$ of the cases were under the age of fifty years, and 58.4\% ( $\mathrm{n}=$ 45) were over fifty years of age. The tissue weights were varied between 100 and 1400 grams, with an average of $623.05 \pm 338.40 \mathrm{~g}$.

Table 1: Demographic data

\begin{tabular}{|c|c|c|c|}
\hline & & Min-Max & median \pm SD \\
\hline \multirow{3}{*}{$\begin{array}{l}\text { Age } \\
\text { Specimen } \\
\text { Weight (gr) }\end{array}$} & & $28-71$ & $51,69 \pm 9,42$ \\
\hline & & $100-1400$ & $623,05 \pm 338,40$ \\
\hline & & $\mathbf{n}$ & $\%$ \\
\hline \multirow[t]{2}{*}{ Age } & $<50$ & 32 & 41,6 \\
\hline & $>50$ & 45 & 58,4 \\
\hline COPD & & 5 & 6,5 \\
\hline DM & & $\begin{array}{l}1 \\
1\end{array}$ & 14,3 \\
\hline HT & & $\begin{array}{l}2 \\
2\end{array}$ & 28,6 \\
\hline Obesity & & $\begin{array}{l}1 \\
9\end{array}$ & 24,7 \\
\hline Smoker & & $\begin{array}{l}2 \\
1 \\
\end{array}$ & 27,3 \\
\hline \multirow[t]{3}{*}{ SIDE } & Bilateral & 46 & 59,7 \\
\hline & Right & 14 & 18,2 \\
\hline & Left & 17 & 22,1 \\
\hline \multirow[t]{2}{*}{$\begin{array}{l}\text { Surgical } \\
\text { Technique }\end{array}$} & $\begin{array}{l}\text { İnferior } \\
\text { pedicule }\end{array}$ & 57 & 74,0 \\
\hline & $\begin{array}{c}\text { Superior } \\
\text { pedicule }\end{array}$ & 20 & 26,0 \\
\hline \multirow{3}{*}{$\begin{array}{l}\text { Specimen } \\
\text { Weight (gr) }\end{array}$} & $<500$ & 30 & 39,0 \\
\hline & $500-1000$ & 32 & 41,6 \\
\hline & $>1000$ & 15 & 19,5 \\
\hline
\end{tabular}

It is seen that $6.5 \%$ of cases $(n=5)$ had chronic obstructive pulmonary disease (COPD), $14.3 \%$ $(\mathrm{n}=11)$ had diabetes mellitus (DM), $28.6 \%$ ( $\mathrm{n}$ = 22) had hypertension(HT), $24.7 \%(\mathrm{n}=19)$ had obesity and $27.3 \%(n=21)$ of them were smokers. Patients with BMI 30 and above were defined as obese.

Inferior pedicle was used in $57(74 \%)$ patients, and superior pedicle technique was used in 20 (26\%) patients. Symmetrisation was performed with 46 patients $(59.7 \%)$.
Wound complications during the early period were observed in 18 patients $(23.4 \%)$. In particular $16.9 \%$ of patients $(\mathrm{n}=13)$ exhibited wound dehiscence, $3.9 \%(\mathrm{n}=3)$ of them exhibited infection and $2.6 \%(n=2)$ had hematoma. Patients with wound infection were treated with oral antibiotics. 4 of 13 patients who developed wound dehiscence treated with primary suture and nine patients showed improvement after medical dressing.

Specimen weights were under 500 grams in $39 \%$ of the cases $(\mathrm{n}=30), 41.6 \%(\mathrm{n}$ $=32$ ) were between 500 and 1000 grams, and $19.5 \%(\mathrm{n}=15)$ were more than 1000 grams.

In the postoperative period, it is seen that $75.3 \%$ of cases $(n=58)$ were administered with adjuvant chemotherapy and hormonal therapy. The average time it takes for patients to begin adjuvant treatment was determined as 19 days (min: 11 days - max: 27 days).

Sentinel lymph node biopsy (SLNB) was performed for $88.3 \%$ of the patients $(n=68)$. Concurrent axillary dissection was included in the procedure for $31.2 \%$ of the patients $(\mathrm{n}=$ 24).

According to the pathology reports of the patients; $7.8 \%$ of cases $(n=6)$ were Tis, $29.9 \%(\mathrm{n}=23)$ were $\mathrm{T} 1,53.2 \%(\mathrm{n}=41)$ were $\mathrm{T} 2$ and $9.1 \%(\mathrm{n}=7)$ were $\mathrm{T} 3$ tumors. Also according to the status of axilla; $67.5 \%$ of cases $(\mathrm{n}=52)$ were N0, \% $24.7(\mathrm{n}=19)$ were $\mathrm{N} 1,3.9 \%(\mathrm{n}=3)$ were $\mathrm{N} 2$ and the $3.9 \%(\mathrm{n}=3)$ were N3.

When cases evaluated by age, a statistically significant difference $(p<0,05)$ is determined between age groups. The rate of complications for the patients older than 50 was higher. When we calculated odds ratios by age, it was found as 4.833 (95\% CI: 1,265$18,469)$, and these data shows that risk of early complications in patients over 50 is 4.83 times higher.

The rates of COPD, DM, obesity, and smoking did not cause any statistically significant difference with regard to early stage complication. The incidence of early-stage wound complications is significantly higher in hypertensive patients. The ratio of ODDS in accord with HT was determined as 4,896 (95\% CI: 1,589-15,084). Accordingly, the risk of developing early-stage complications in hypertensive patients found 4.89 times higher (Table-2). 
When the early stage complication rates of patients who had SLNB evaluated, a statistically significant difference was not found ( $p>0.05$ ). Similarly, patients who had axillary dissection showed no increase of early stage complication rates $(\mathrm{p}>0.05)$.

No statistically significant difference was found between surgical methods applied $(p>0.05)$. It has been shown that the rate of early-stage complication development has not increased in patients undergoing bilateral reduction mammoplasty $(\mathrm{p}>0.05)$.
Statistically, a significant difference was found between the weights of the tissues removed from the cases according to the early complication ( $\mathrm{p}<0.01)$. The weight of tissue removed in patients showing early complication was significantly lower than those without early complication. The early complication rate was significantly lower for the patients whose removed tissue weight was below 500 grams $(\mathrm{p}<0.05)($ Table -3$)$.

Table 2: Comorbidities - Complication rate

\begin{tabular}{|c|c|c|c|}
\hline & \multicolumn{3}{|c|}{ Early complication } \\
\hline & $\begin{array}{l}\text { No }(\mathbf{n}=59) \\
\text { n }(\%)\end{array}$ & $\begin{array}{c}\text { Yes }(\mathbf{n}=18) \\
\mathbf{n}(\%)\end{array}$ & $\mathbf{p}$ \\
\hline COPD & $3(\% 5,1)$ & $2(\% 11,1)$ & 0,332 \\
\hline Diabetes Mellitus & $6(\% 10,2)$ & $5(\% 27,8)$ & 0,116 \\
\hline${ }^{+}$Hypertension & $12(\% 20,3)$ & $10(\% 55,6)$ & $0,009 * *$ \\
\hline Obesity & $14(\% 23,7)$ & $5(\% 27,8)$ & 0,760 \\
\hline Smoker & $14(\% 23,7)$ & $7(\% 38,9)$ & 0,235 \\
\hline Fisher's Exact Test & ${ }^{+}$Yates Continity Correction & $* p<0,05$ & $* * p<0,01$ \\
\hline
\end{tabular}

Table 3: Early Complication - Specimen Weight

\section{Complication}

$\begin{array}{lrrr}\text { No }(n=59) & \text { Yes }(n=18) & { }^{+} \\ \text {Mean } \pm \text { SD } & \text { Median } & \text { Mean } \pm \text { SD } & \text { Median }\end{array}$

\begin{tabular}{llllll}
\hline $\begin{array}{l}\text { Specimen Weight } \\
\text { (gr) }\end{array}$ & $823,89 \pm 291,13$ & 765 & $561,78 \pm 329,96$ & 500 & $\mathbf{0 , 0 0 3 * *}$
\end{tabular}

\begin{tabular}{|c|c|c|}
\hline n (\%) & n (\%) & ${ }^{++} p$ \\
\hline \multicolumn{3}{|l|}{$\begin{array}{l}\text { Specimen Weight } \\
\text { (gr) }\end{array}$} \\
\hline$<\mathbf{5 0 0 2 8}(\% 47,5)$ & $2(\% 11,1)$ & \\
\hline $\mathbf{5 0 0 - 1 0 0 0 2 2}(\% 37,3)$ & $10(\% 55,6)$ & $0,017 *$ \\
\hline$>\mathbf{1 0 0 0 9}(\% 15,3)$ & $6(\% 33,3)$ & \\
\hline
\end{tabular}


Table - 4: Logistic regression analysis of the factors effecting complication rates

\begin{tabular}{|c|c|c|c|c|c|}
\hline & & \multirow[t]{2}{*}{$\mathbf{p}$} & \multirow[t]{2}{*}{ Odds } & \multicolumn{2}{|c|}{$\% 95 \mathrm{CI}$} \\
\hline & & & & Lower & Upper \\
\hline Age $\geq 50$ & & 0,183 & 2,780 & 0,618 & 12,502 \\
\hline DM & & 0,784 & 1,249 & 0,255 & 6,131 \\
\hline HT & & $0,046 *$ & 3,358 & 1,024 & 11,010 \\
\hline \multirow[t]{3}{*}{ Specimen weight } & $<\mathbf{5 0 0}$ & 0,113 & & & \\
\hline & \multicolumn{2}{|c|}{$500-10000,082$} & 4,421 & 0,826 & 23,653 \\
\hline & \multicolumn{2}{|c|}{$>10000,040 *$} & 6,759 & 1,091 & 41,860 \\
\hline
\end{tabular}

When we evaluated the effects of DM, HT and weight of removed tissue with the early complications by using Backward Stepwise Logistic regression analysis; it is seen that the model is descriptive and meaningful and its coefficient of determination proved to be at high levels (76.6\%). In the model, HT and tissue weight were determined as independent risk factors; and it is seen that the effect of ODDS ratio of HT on early complications has 3,358 times (\%95 CI:1,02-11,01) and tissue weight above $1000 \mathrm{~g}$ has the ODDS value of 6.759 (95\% CI: 1.09-41,86) times higher. Accordingly, the risk of early complication increases with the weight of removed tissue (Table-4).

\section{DISCUSSION}

The number of patients in studies, that investigate wound complications in reduction mammoplasty performed in breast cancer, are relatively low. Eight minor complications and no major complications were identified, in the study of Spear et al. which had performed 22 breast reduction surgeries of breast cancer patients (5). In the same study; during two-year follow-up, no local recurrences, no delays in adjuvant radiotherapy and chemotherapy were reported. In Thornton's series consisting of 6 patients, no complications have developed, and no adjuvant therapy delays were reported (6).

Series which reports the results of surgeries performed for macromastia are larger. For example, in the study of Grant et al., consisting of 444 benign patients, the minor complication rate is $14 \%$ (7). The main complications were nipple necrosis in 2 patients and pulmonary embolism in 1 patient.

The complication rates reported in the literature vary between 10 to $91 \%$ in the reduction mammoplasty operations performed for both malignant and benign reasons (8-13). A recent systematic review of OBCS reported postoperative complications occurred in $14.3 \%$ of patients, including liponecrosis $3.3 \%$, skin necrosis $0.5 \%$, hematoma $2.5 \%$, seroma $1.0 \%$, delayed wound healing $2.2 \%$, nipple necrosis $0.4 \%$ and/or infection $1.9 \%$ (14). Reporting and classification of surgical complications are very highly variable.

High complication rates may cause adjuvant treatment delays in breast cancer patients. In studies that specify delays in adjuvant therapy, delay rates vary between $1.9 \%$ and $6 \%(15-18)$. When the patients included in our study were examined, none of the patients showed any delay in their 
treatment. The average time to start adjuvant treatment was 19 days. Current guidelines recommend that adjuvant treatment should be commenced as soon as clinically possible within 31 days of completion of surgery (19).

Seroma is the most common complication after mastectomy. Dead space forming after removing a large tissue is the mechanism most commonly accused in the seroma pathophysiology. After reduction mammaplasty techniques, in which a fairly wide tissue is removed, the seroma occurance rates are usually acceptable.

Hematoma, deemed as one of the most common wound complications in a similar manner to seroma, can easily be prevented with the appropriate hemostasis. Besides, the preoperative bleeding parameters must most certainly be checked, medications effecting bleeding should be discontinued. Infection is another complication which can be prevented by providing appropriate sterilization conditions before and during the operation.

Wound dehiscence occurs most frequently in $\mathrm{T}$ junction regions. Frequent stitches and the tension of tissues may be the reasons of wound dehiscence. Another cause of wound dehiscence and delayed wound healing may be superficial infections that are not recognized. The most common minor complication has been determined to be wound dehiscence at the $\mathrm{T}$ junction region, especially for the patients that the inferior pedicle technique was performed $(20,21)$. It was reported in the study of Shah et al. which evaluate the wound dehiscence in patients who had undergone reduction mammoplasty, that smoking and comorbid diseases increase the rate of wound dehiscence (22).

Nipple necrosis is the most severe wound complication seen after OBCS. Mostly technical factors are responsible such as the width of the base of pedicle, enough tissue left behind areola, distance between sternal notch or clavicle and areola (23). In our study, no patient developed flap and NAC necrosis.

Our early complication rate was found to be $23.4 \%$. As the patient age, the number of comorbid diseases that affect wound healing and removed tissue volume increases, complication rates are known to increase as well. Advanced age was defined as an independent risk factor known to delay in wound healing (24). In their study evaluating factors affecting wound healing in patients with breast cancer, Ruvalcaba-Limon et al. have determined that age $(>50 \mathrm{y})$ is an independent factor increasing the risk of wound complications (25). In our study, 50 years and older patients seen in early complication rates to be high.

Similarly, the HT is known to negatively affect wound healing. We also study the incidence of HT in patients with early complications seen significantly higher.

DM and chronic lung diseases negatively affect healing of the wound by causing peripheral circulation disorders, like HT. In our study, the rate of early wound complications in patients with these risk factors was higher than the patients without such comorbidities however no statistically significant difference was not found between these two groups.

In many studies, obesity and high BMI was found to be as complication rate increasing factors in mammoplasty surgery. Gamboa-Bobadilla et al. have determined wound complication rates after mammoplasty to be $21 \%$ with overweight patients, $43 \%$ with obese patients and $71 \%$ with morbidly obese patients (26). Obese patients have more breast volume; therefore, as more breast tissue is removed, it is known to increase the rate of complications (27-29). It is known that vascular perfusion of obese patients is insufficient. This may explain wound dehiscence. Fat necrosis, which is common in obese patients, can also be associated with increased seroma ratios. In our study, patients have an average BMI of $24 \pm 3$, and only $24.7 \%$ of them are evaluated as obese. In the studies which reduction mammoplasty is performed for macromastia, the average BMI is 27 or higher (29).

The most commonly used breast reduction technique for both malignant and benign patients is inferior pedicle technique. Mandrekas et al. (30) have evaluated in their series, the complications on 371 patient, who had this technique applied and total complication rate was found to be $11.4 \%$. In this series, the most common wound complication was specified as wound dehiscence experiencing this problem have been pointed at the $\mathrm{T}$ zone area. Besides this 
inferior pedicle technique has the most satisfying cosmetic results. We also used the inferior pedicle technique more often. Considering that most breast tumors occur in the upper outer quadrant, the inferior pedicle technique is an appropriate approach for many breast tumors. In our study, we compared patient groups who had surgeries with two different OBCS techniques. There was no statistically significant difference in wound complications between these two techniques.

In our study, the patients were divided into three groups as $<500 \mathrm{~g}, 500-1000 \mathrm{~g}$, $>$ $1000 \mathrm{~g}$ according to the removed tissue weight. Wound complications were found to be significantly less in the group that underwent tissue removal under 500g. Some studies show that the complication rates increase with excised tissue weight; which is similar with our findings (31).

\section{CONCLUSIONS}

In the treatment of breast cancer, OBCS techniques have been preferred more and more with the disappearance of concerns about BCS. Oncoplastic surgery allows for wider excision of breast tumors without compromising good cosmetic results.

Rates of complications, which may arise as a result of many surgical techniques that may be used for breast cancer treatment, can be minimized with detailed preoperative evaluation, a careful surgical technique. Surgical wound complications can be affected by the factors related to the patient, besides the surgical techniques. Therefore, during preoperative evaluation; conditions which may affect wound healing in postoperative period such as obesity, DM, smoking, chronic lung disease and HT should be investigated.

While a consensus was not achieved on this subject (1), OBCS techniques can safely be used without increasing the complication rates.

\section{REFERANSLAR}

1. Weber WP, Soysal SD, El-Tamer M, et al. First international consensus conference on standardization of oncoplastic breast concerving surgery. Breast Cancer Res Treat. 2017;165. 139149.
2. Clough KB. Cosmetic Sequela After Conservative Treatment For Breast Cancer: Classification And Results Of Surgical Correction. Ann Plast Surg (1998); 41:471-481.

3. Association of Breast Surgery at BASO; Association of Breast Surgery at BAPRAS; Training Interface Group in Breast Surgery, et al. Oncoplastic breast surgery - A Guide To Good Practice. EJSO (2007); 33: 1-23.

4. MG Berry. Oncoplastic Breast Surgery: A Review And Systematic Approach. J Plast Reconst Aest Surg (2010) 63, 1233-1243.

5. Spear SL, Pelletiere CV, Wolfe AJ, Tsangaris TN, Pennanen MF. Experience with Reduction Mammaplasty Combined with Breast Conservation Therapy in the Treatment of Breast Cancer. Plast Reconstr Surg. (2003); 111: 1102-1109.

6. Thornton BP, Stewart DH, McGrath PC, Pu LL. Breast Reduction as an Alternative Treatment Option for Early Breast Cancer in Women with Macromastia. Ann Plast Surg. (2006); 56: 26-30.

7. Grant SW, Andrew JL, David A, Elliot M. Outpatient Reduction Mammaplasty: An Eleven Year Experience. Aesth Surg J. (2008); 28: 171-179.

8. J.McIntosh, J.M. O'Donoghue. Therapeutic Mammaplasty - A Systematic Review of the Evidence. ESJO. (2012); 38: 196 - 202.

9. CampbellEJ, RomicsL.Oncological safety and cosm etic outcomes in oncoplastic breast conservation sur gery, a review of the best level of evidence literature. Breast Cancer (Dove Med Press). 2017; 9: 521-530.

10. Mattingly AE, Ma Z, Smith PD, et al. CME Article: Early Postoperative Complications after Oncoplastic Reduction. South. Med. J. 2017;110. 660-666.

11. EmirogluM, SertI, KaraaliC, AksoySO, UgurluL, A ydinC.The effectiveness of simultaneous oncoplastic breast surgery inpatientswithlocallyadvanced breast cancer.Breast Cancer. 2016;23:463-70.

12. Emiroglu M, Salimoglu S, Karaali C, et al. Oncoplastic reduction mammoplasty for breast cancer in women with macromastia: Oncological long-term outcomes. Asian J Surg. 2017;40:41-47.

13. GulcelikMA, DoganL, CamlibelM,etal.Early compli cations ofa reduction mammoplasty technique inthe $t$ reatment of macromastia with or without breast cancer. Clin Breast Cancer. 2011;11:395-9.

14. De La Cruz L, Blankenship SA, Chatterjee A, et al. Outcomes After Oncoplastic Breast-Conserving Surgery in Breast Cancer Patients: A Systematic Literature Review. Ann Surg Oncol. 2016;23:324758.

15. Fitoussi AD, Berry MG, Fama F et al. Oncoplastic Breast Surgery for Cancer: Analysis of 540 Consequtive Cases [outcomes article]. Plast Reconstr Surg (2010); 125: 454-462.

16. Clough KB, van la Parra RFD, Thygesen $\mathrm{HH}$, et al. Long-term Results After Oncoplastic Surgery for Breast Cancer: A 10-year Follow-up. Ann Surg. 2018;268:165-171.

17. MeretojaTJ, SvarvarC, JahkolaTA.Outcome of onco plastic breast surgery in 90 prospective patients. Am J Surg. 2010;200:224-8. 
18. Nos C, Fitoussi A, Bourgeois D, Fourquet A, Salmon RJ, Clough KB. Conservative Treatment of Lower Pole Breast Cancers by Bilateral Mammaplasty and Radiotherapy. Eur J Surg Oncol (1998); 24: 508-514.

19. National Institute for Health and Care Excellence, "Nice 2009 Cg80". Available from: https://www.nice.org.uk/guidence/cg80>.

20. Mandrekas AD, Zambacoa GJ, Anastasopoulos A, Hapsas DA. Reduction Mammaplasty With the Inferior Pedicle Technique: Early and Late Complications in 371 Patients. Br J Plast Surg (1996), 49: 442-446.

21. Stevens WG, Gear AJ, Stroker DA, Hirsch EM, Cohen R, Spring M. Outpatient Reduction Mammaplasty: An Eleven Year Experience. Aest Surg J (2008), 28: 171-179.

22. Shah R, Al-Ajam Y, Stott D, Kang N. Obesity in Mammaplasty: A Study of Complications Following Breast Reduction. J Plast Recons Aest Surg (2011); 64: 508-514.

23. Setälä L, Papp A, Joukainen S, et al. Obesity and Complications in Breast Reduction Surgery: Are Restrictions Justified J Plast Reconstr Aesthet Surg. (2009); 62: 195- 199.

24. Gurtner GC, Wong VW. Wound Healing:Normal and Abnormal. Galiano RD, Mustoe TA. Wound Care In: Thorne $\mathrm{CH}$ ed. Grabb\&Smith's Plastic Surgery, (7th ed). Wolters Kluwer/Lippincott Williams\&Wilkins;2014:13-19.

25. Ruvalcaba-Limon E, Robles-Vidal C, PoitevinChacon A, Chavez- MacGregor M. Complications
After Breast Cancer Surgery in Patients Treated With Concomitant Preoperative Chemoradiation. Breast Cancer Research and Treatment (2006), 95: 147-152.

26. Gamboa-Bobadilla GM, Killingsworth C. LargeVolume Reduction Mammaplasty:The Effect Of Body Mass Index On Postoperative Complications. Ann Plast Surg (2007); 58:246-249.

27. Zubowski R, Zins JE, Foray-Kaplon A, et al. Relationship of Obesity and Specimen Weight to Complications in Reduction Mammaplasty. Plast Reconstr Surg (2000); 106: 998-1003.

28. Cunningham BL, Gear AJ, Kerrigan CL, Collins ED. Analysis Of Breast Reduction Complications Derived From The BRAVO Study. Plast Reconstr Surg. (2005) May; 115: 1597-1604.

29. Nelson JA, Fischer JP, Chung CU, et al. Obesity and early complications following reduction mammaplasty: an analysis of 4545 patients from the 2005-2011 NSQIP datasets. J Plast Surg Hand Surg. 2014;48:334-9.

30. Mandrekas AD, Zambacoa GJ, Anastasopoulos A, Hapsas DA. Reduction Mammaplasty With the Inferior Pedicle Technique: Early and Late Complications in 371 Patients. Br J Plast Surg (1996), 49:442-446.

31. Anzarut A, Edwards DC, Calder K, Guenther CR, Tsuyuki R. Superior Pedicle Breast Reduction Techniques Increase The Risk Of Postoperative Drainage. Ann Plast Surg (2008), 60: 367-371. 